\section{診療所における医師の治験に対す る意識調査}

丸山由起子 中田忍 岡安章江 前田百恵 内田安重

【目的】診療所における治験実施が年々増加傾 向にある。我々は、SMO として診療所の治験 に係っているが、実際には、医師は不安や抵抗 を抱いていることも否定できない。今回、診療 所におけるより円滑な治験実施のために SMO ができることは何かを考察するために、治験を 実施する前後での治験に対する医師の意識の 変化、治験実施における業務負担、今後の治験 についての希望・要望などの意識調査を行った ので報告する。

【方法】平成 15 年 7 月 29 日〜 8 月 18 日の期 間において、当社にて新 GCP 施行以降に診療 所において治験（市販後臨床試験を含む）を実 施した医師 95 名を対象とし、郵送又は手渡し による質問紙を用いて調查を実施した。

【結果】回収率は $56 \%$ (53 名/95 名)であった。 治験実施前は、診療所では、「治験は実施でき ない」又は「難しい」と考えていた医師は $55 \%$ であった。その理由には、時間的余裕がない $62 \%$ 、緊急時の適切な対応への不安（安全に実 施できない） $55 \%$ 、スタッフの不足 $55 \%$ であ つた。

治験を開始してからの日常診療業務の変化 については、「忙しくなった」が $60 \%$ を占めて いた。その理由には、CRA や CRC による拘束 $72 \%$ 、被験者との診察に時間が掛かる $50 \%$ 、 症例報告書の作成に時間が掛かる $34 \%$ あっ た。

被験者の組入れのための CRC によるカルテ スクリーニングについては $30 \%$ の医師が実施 しなかった。その理由としては、受診患者を全 て把握しているので必要性を感じなかった $50 \%$ 、職員以外に無差別にカルテを見られるこ とに抵抗があった $31 \%$ であった。

治験終了後、治験に対する考え方の変化につ いては、より興味深いものとなった $32 \%$ 、今後 もより積極的に実施していきたい $30 \%$ 、実施で きないと思っていたができることがわかった $36 \%$ 、困難は伴うが実施できることがわかった $25 \%$ 、二度と治験は実施したくない $2 \%$ あっ た。

株式会社イーピーリンク

サイトサポート事業本部 業務部

テ103-0023 東京都中央区日本橋本町 2-5-11NTA 本町ビル 7 階
今後、治験の依頼があったらまた実施したい かについては、96\%の医師が実施したいと回答 した。そのうち、第吕相試験であれば実施した い $26 \%$ 、市販後臨床試験（第 $\mathrm{N}$ 相）であれば実 施したい $75 \%$ 、専門分野が合えば実施したい $55 \%$ 、患者数の多い疾患が対象であれば実施し たい $41 \%$ 、新聞広告などの呼びかけがある治験 であれば実施したい $29 \%$ であった。

診療所における治験実施には、SMO 及び CRC の存在が必要であるとの回答が $94 \%$ あ った。

【結論】治験実施前は、「診療所では治験を実 施できない・難しい」との回答が半数以上であ ったのに対し、実施後では、「今後も治験を実 施していきたい」との回答が大半を占めるよう に変化した。ただし、治験に対して不安を感じ る要因として、「拘束時間の増大 (時間的要素)」、 「院内スタッフの不足 (人員的要素) 、「緊急 時の迅速対応（安全確保要素）」、実施するため の要因としては、「専門分野と合致する対象疾 患の治験 (専門的要素)」、「第血相試験又は市 販後臨床試験（治療的要素）」であることが明 らかになった。

【考察】治験実施後の意識調查において、「考 えていたより楽にできた」が「考えていたより も大変だった」を上回っていること、SMO 及 び CRC の必要性を 9 割以上が認めていること から、適切なサポートが反映された結果として、 診療所における医師の治験に対する意識の変 化があったのはないかと考える。しかし、診療 所においては、医師 1 名、少ないスタッフ数、 入院設備が設けられていない等の診療所特有 の負担要因が生じることは避けられず、更なる 環境整備が SMO に求められている。150 とも 200 ともいわれる SMO が存在する中、医療機 関から選ばれる SMO になるべく、我々は、CRC のみならず、治験事務局担当者のさらなる質の 向上のために努力を重ねていきたい。 